\title{
Geoelectrical investigation of aquifer problems in Gosa area of Abuja, North Central, Nigeria
}

\author{
Omeje M. ${ }^{1 \star}$, Husin W. ${ }^{1}$, Noorddin I. ${ }^{2}$, Oha I. A. ${ }^{3}$, Onwuka O.S ${ }^{3}$, Ugwuoke P. E. and Meludu O. ${ }^{5}$ \\ ${ }^{1}$ Department of Physics, Faculty of Science, Universiti Teknologi Malaysia, 81310, Johor Bahru, Malaysia. \\ ${ }^{2}$ Centre for Research and Innovation Management, National Defence University, Malaysia. \\ ${ }^{3}$ Department of Geology, University of Nigeria Nsukka, Enugu State, Nigeria. \\ ${ }^{4}$ Centre for Energy Research and Development, University of Nigeria, Nsukka, Enugu State, Nigeria. \\ ${ }^{5}$ Department of Physics, School of Pure and Applied Sciences, Federal University of Technology, Yola, Nigeria.
}

Accepted 8 April, 2013

\begin{abstract}
The study of aquifer problems in Gosa area of Abuja, North-central Nigeria, has been undertaken. Abuja, the capital city of Nigeria, is underlain by Precambrian basement rocks. Vertical electrical sounding (VES) was carried out at twelve locations within and around the Gosa area. The interpretation of the data obtained from the sounding revealed that six non-aquiferous geoelectrical layers overlie the unfractured basement. The first layer with average thickness of about $0.5 \mathrm{~m}$ and resistivity of $83 \mathrm{Ohm}$ $\mathrm{m}$. The thickness of the second layer is about $0.7 \mathrm{~m}$ and resistivity of $438 \mathrm{Ohm}-\mathrm{m}$. The third layer is about $3.4 \mathrm{~m}$ thick and resistivity of about $63 \mathrm{Ohm}-\mathrm{m}$. The fourth layer with average thickness of about $16.0 \mathrm{~m}$ and resistivity, $236 \mathrm{Ohm}-\mathrm{m}$. The fifth layer with average thickness of $42.7 \mathrm{~m}$ and resistivity of about $68 \mathrm{Ohm}-\mathrm{m}$. The thickness of sixth layer varies from $42.7 \mathrm{~m}$ to infinity and resistivity of about 2067 Ohm-m. Eight boreholes of varying depths, 45 to $70 \mathrm{~m}$ were drilled. Other areas were drilled with good yield of static water level of about $3.7 \mathrm{~m}$, whereas Gosa aquifers were found dried. It could be attributed to basaltic intrusion that shattered the aquifer bearing rocks thereby devoid water in the zone after pronouncing from geophysical investigation.
\end{abstract}

Key words: Geologic map, accessibility map, vertical electrical sounding (VES) profiles.

\section{INTRODUCTION}

Basement complex rocks do not inherently make good aquifers. The hydrogeologic characteristics of basement rocks are only enhanced when the rocks are fractured and/or when they are weathered. The conditions are better enhanced when the rocks are overlain by thick overburden. Groundwater potentials of a basement complex area are often determined by geophysical means, which determines the thickness of the overburden and the network of fractures that may exist in the area. Geophysical surveys are also important for groundwater investigation in basement areas in view of the discontinuous (localized) nature of basement aquifers (Satpatty and Kanugo, 1976). The use of the vertical electrical sounding (VES) method is popular for groundwater investigation in both soft rock (sedimentary) and hard rock (igneous and metamorphic) terrains (Barongo and Palacky, 1989; De Beer and Blume, 1985; Mbonu et al., 1991; Shemang, 1993). In the Basement Complex of Nigeria, extensive application of geoelectrical method for groundwater investigation has been reported (Pulawski and Kurth, 1977; Acworth, 1987; Olorunfemi and Okankune, 1992; Olorunfemi and Fasuyi, 1993;

*Corresponding author. E-mail: maxico3333@yahoo.co.uk. 


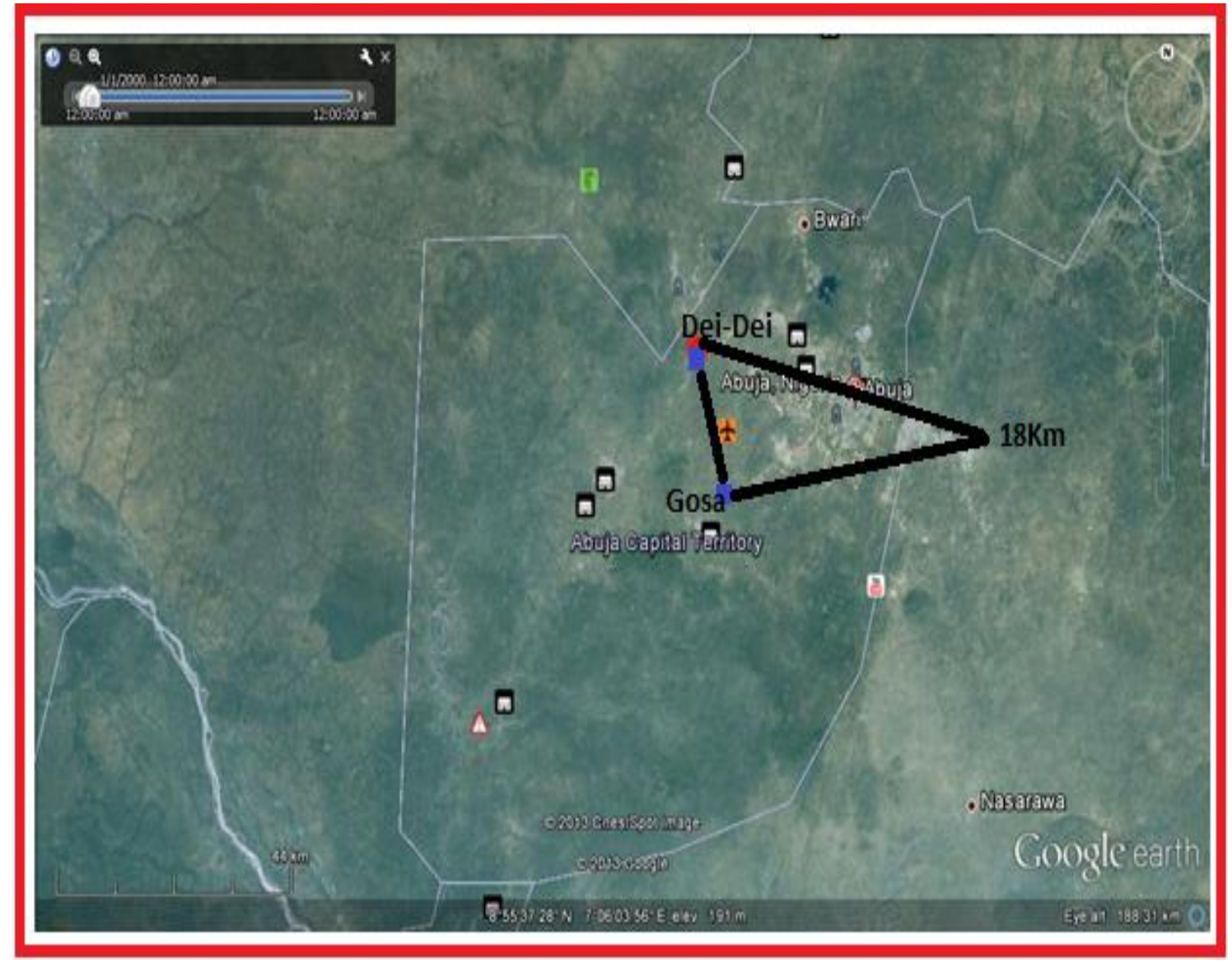

Figure 1. The Google earth map of the study area showing the study arean with blue dot.

Edet and Okereke 1997; Nur and Ayuni, 2004).

The area of study includes most parts of Abuja main city, and western surburbs. It includes areas around Maitama, Asokoro, Wuse, Garki, Gwarimpa, Kado, Jabi, Kubwa, Dei-Dei, Lugbe and Gosa. It is bounded by Latitudes $8^{\circ} 53^{\prime} \mathrm{N}$ to $9^{\circ} 13^{\wedge} \mathrm{N}$ and longitudes $7^{\circ} 00^{\circ} \mathrm{E}$ to $7^{\circ}$ $30^{\circ} \mathrm{E}$. Gosa has become important because of the increasing population of the suburbs of Abuja. Many residents of the area embark on the development of private boreholes to augment public water supplies which are inadequate. But most boreholes here are abortive, and so counter the intentions of the owners, in addition to loss of capital. This work is a first-hand study aimed at establishing the groundwater conditions in the Gosa area of Abuja, Nigeria, which will help in adequate planning and drilling of boreholes in the area.

\section{Geology and hydrogeology of the area}

The area of study forms part of the Basement Complex of north central Nigeria; with lithologic units falling under three main categories, which include (1) Undifferentiated migmatite complex of Proterozoic to Archean origin, (2) Metavolcano-Sedimentary rocks of late Proterozoic age and (3) older granite complex of late Precambrian Lower Paleozoic age, also known as Pan-African granites. All these rocks have been affected and deformed by the Pan-African thermotectonic event. Detailed reports of the lithological description, age, history, structure and geochemistry of the Basement Complex of Nigeria are given in Oyawoye (1972); Black et al. (1979); Ajibade et al. (1987); Rahaman (1988); Caby (1989) and Dada (2008). Figure 1 shows the Google earth map of the location. Figure 2 is the geologic map of Nigeria showing the study area with red arrow.

In the study area, all the three major rock categories mentioned above are well represented (Figure 3). The rocks are generally weathered into reddish micaceous sandy clay to clay materials, capped by laterite. The hydrogeology of basement areas is simple since there is an inherent limitation to the occurrence of groundwater. However, where the regolith is thick, and there is a dense network of fractures, the potentials for the accumulation of groundwater in basement complex rocks may increase. 


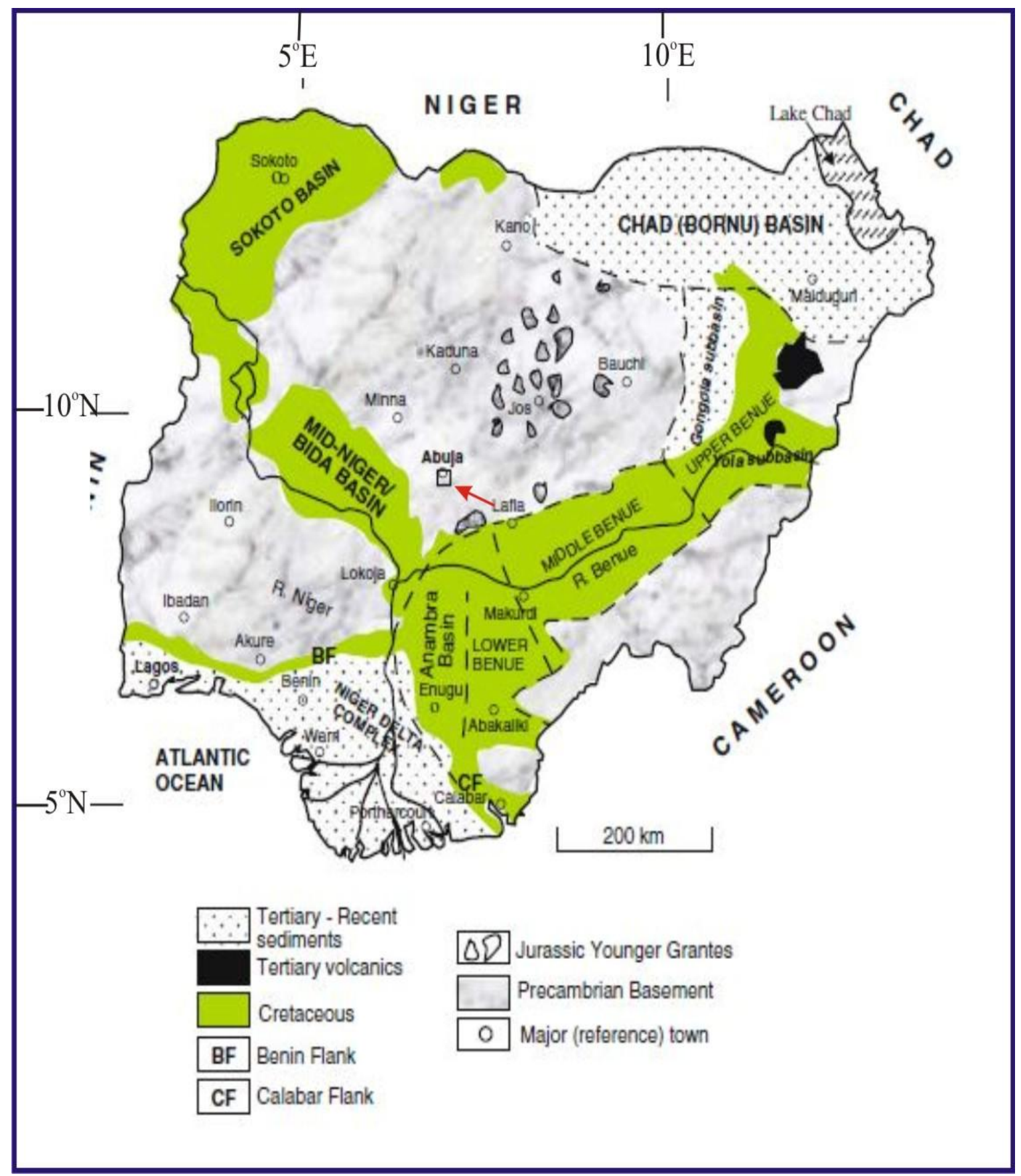

Figure 2. Geological Map of Nigeria, showing the position of Abuja (red arrow) in the Basement Complex of North central Nigeria (modified from Obaje, 2009).

\section{MATERIALS AND METHODS}

\section{Geophysical investigation}

The search for groundwater in Gosa and it's environ was carried out through the use of electrical methods of geophysical survey, (Figure 4). The Schlumberger configuration in VES was used to obtain field data. Vertical electrical sounding probes the vertical variation in resistivity of the subsurface, thereby indicating the presence of fluid and ionic concentration in the subsurface materials. It is also applied to determine the depth to bedrock, delineate the various units that constitute the overburden (regolith), determine the degree of fracturing of the bedrock; all of which would help in making the choice for a feasible site for constructing a successful borehole. VES data for this work were obtained using the Allied Omega C2 Terrameter. The field data obtained was presented as curve of apparent resistivity values against half of the current electrode separation $(A B / 2)$ in metres on a log-log scale. 


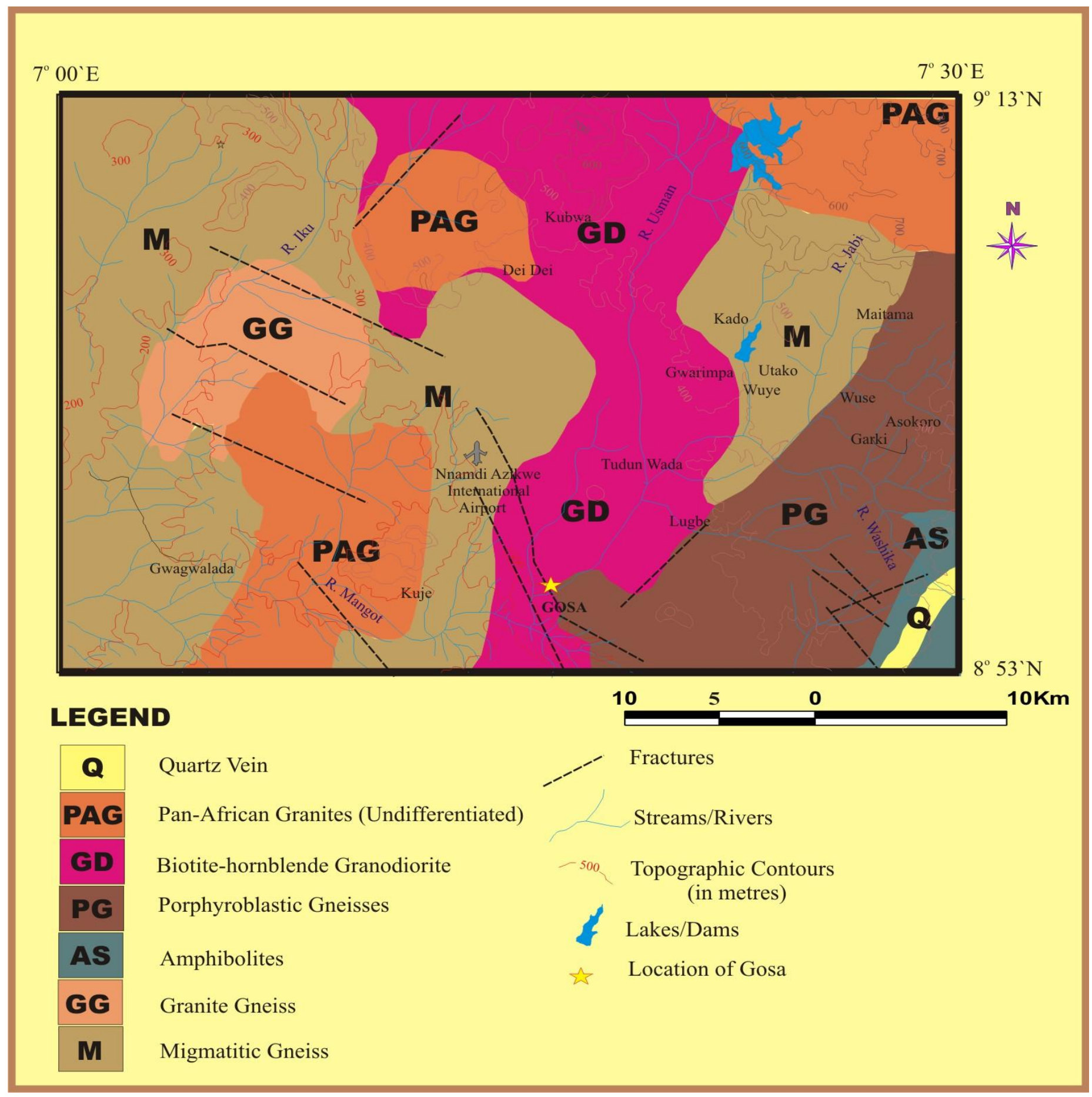

Figure 3. Geological map of the study area.

A 3-mode filter was employed to jettison associated noise due mostly to electrical signals and interference from adjacent power transmission lines. The VES data obtained were analyzed using the WINRESIST 2004 Version computer software to improve the quality of the interpretation by iteration and modelling to goodness of fit. The profiles plots of apparent resistivity against electrode spacing are shown in Figures 5, 6, 7, 8, 9 and 10.

\section{Drilling of boreholes}

\section{Drilling boreholes}

Among the drilled boreholes, two monitoring boreholes for this work were drilled at Dei-Dei and Gosa for proper investigation of 
$7^{\circ} 00^{`} \mathrm{E}$

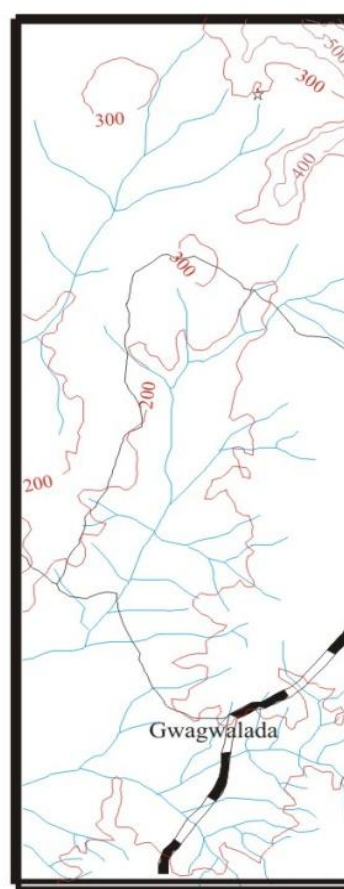

LEGEND $7^{\circ} 30^{`} \mathrm{E}$

$9^{\circ} 13^{\prime} \mathrm{N}$

- $)$ VES Location

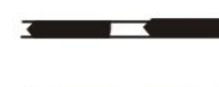

Major Expressway

Streams/Rivers

Major Roads

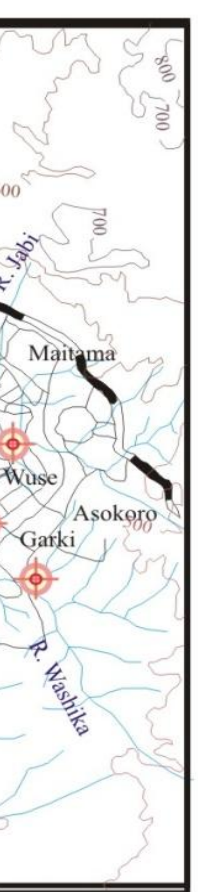

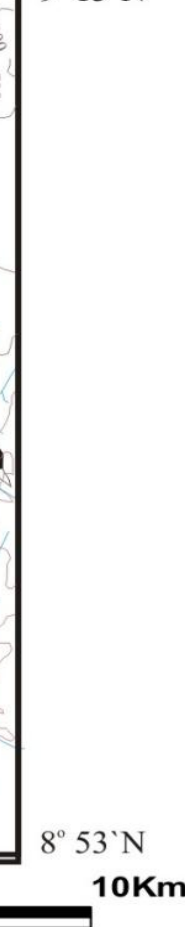

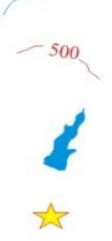

Topographic Contours

(in metres)

Lakes/Dams

Location of Gosa

Figure 4. Accessibility map of the study area, showing positions of VES points.

subsurface step-by-step information with well log and GPS for the coordinates. The boreholes were drilled with the help of 30 ton capacity rig machine with compressor made of INGERSOL. The rocks were clay and sand, and the medium was heterogeneous as the thickness of the different layers differed in the boreholes.

\section{Sample inventory}

The identification of boundaries between layers with noticeably different particle sizes using visual manual logging method, record the thickness when the layer changes. Layer thickness change may range from less than one metre to tens of metres. After boundary of distinct layers have been clearly marked an indelible felt-tipped pen, using a single entry for each layer:

(a) Record the date the sample is logged and the initials of the logger,

(b) Record the designate geologically logged cut segment,

(c) Determine and record the depth interval for each layer,

(d) Photograph each layer using digital camera.

The two sites were Dei-Dei (about $60 \mathrm{~m}$ ), and Gosa (49 to $50 \mathrm{~m}$ ), Figure 3 shows the drilling points.

Site one borehole (S1): Details about the logging are given in Table 2. 


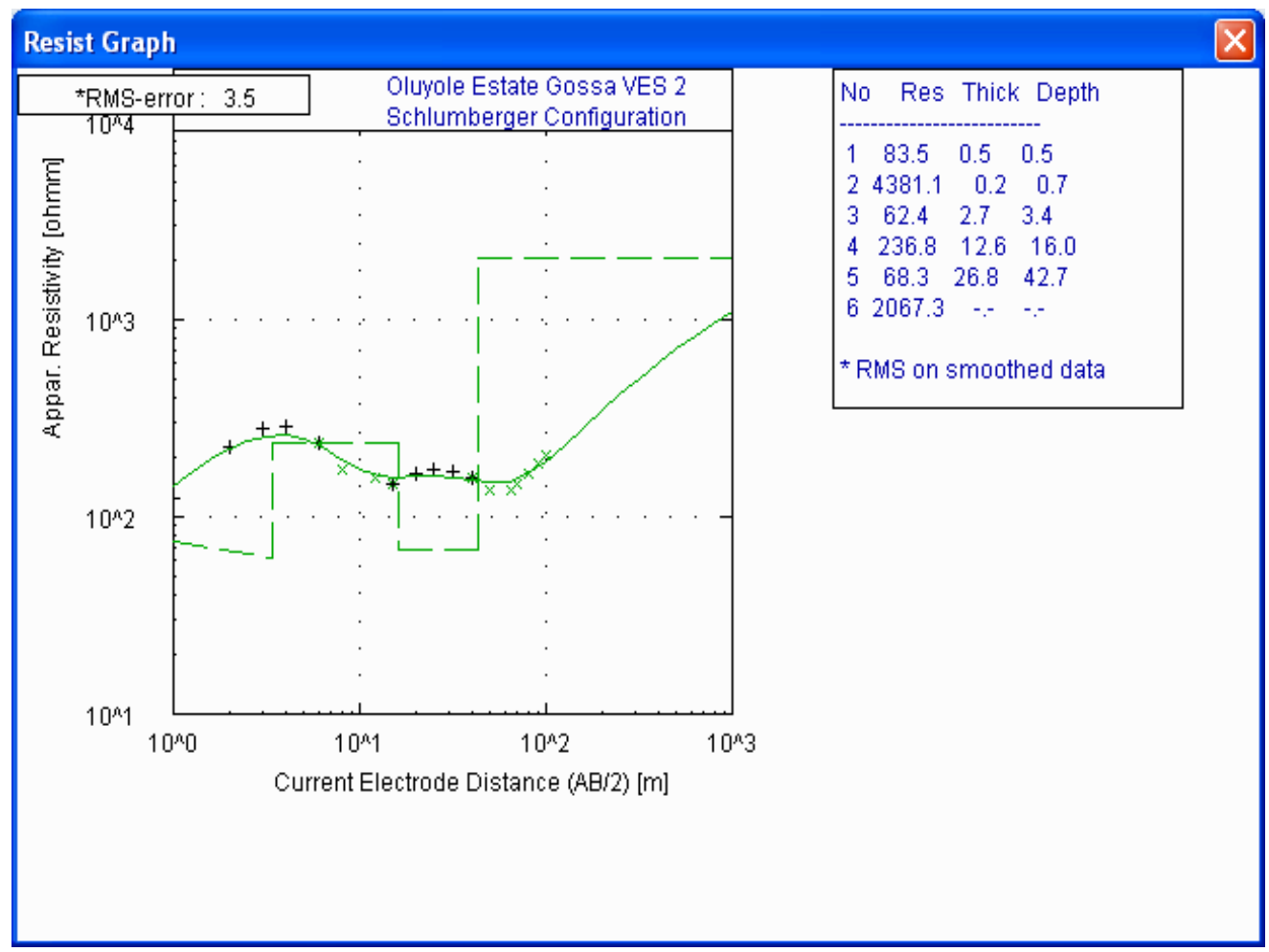

Figure 5. Gosa.

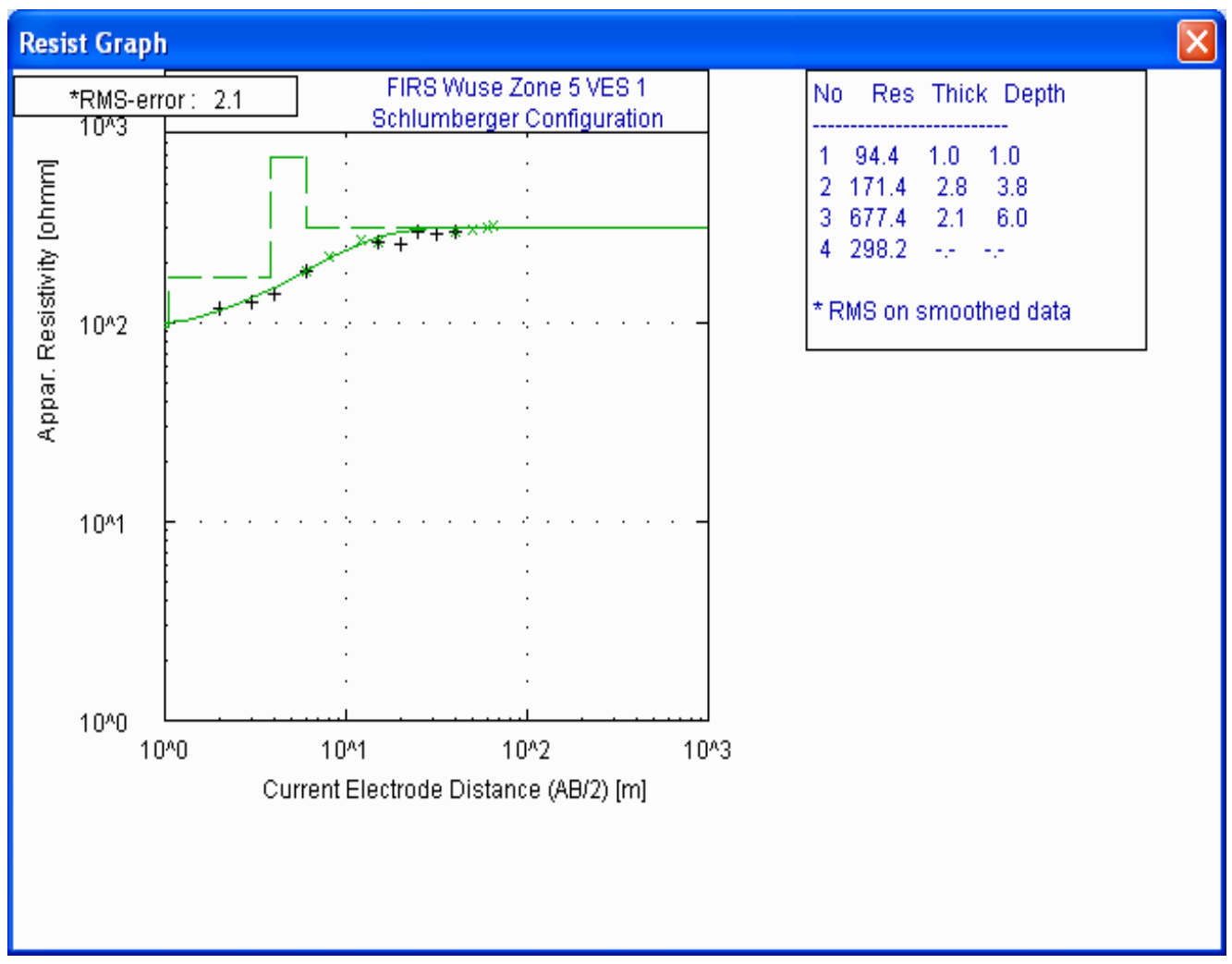

Figure 6. Wuse Zone 5. 


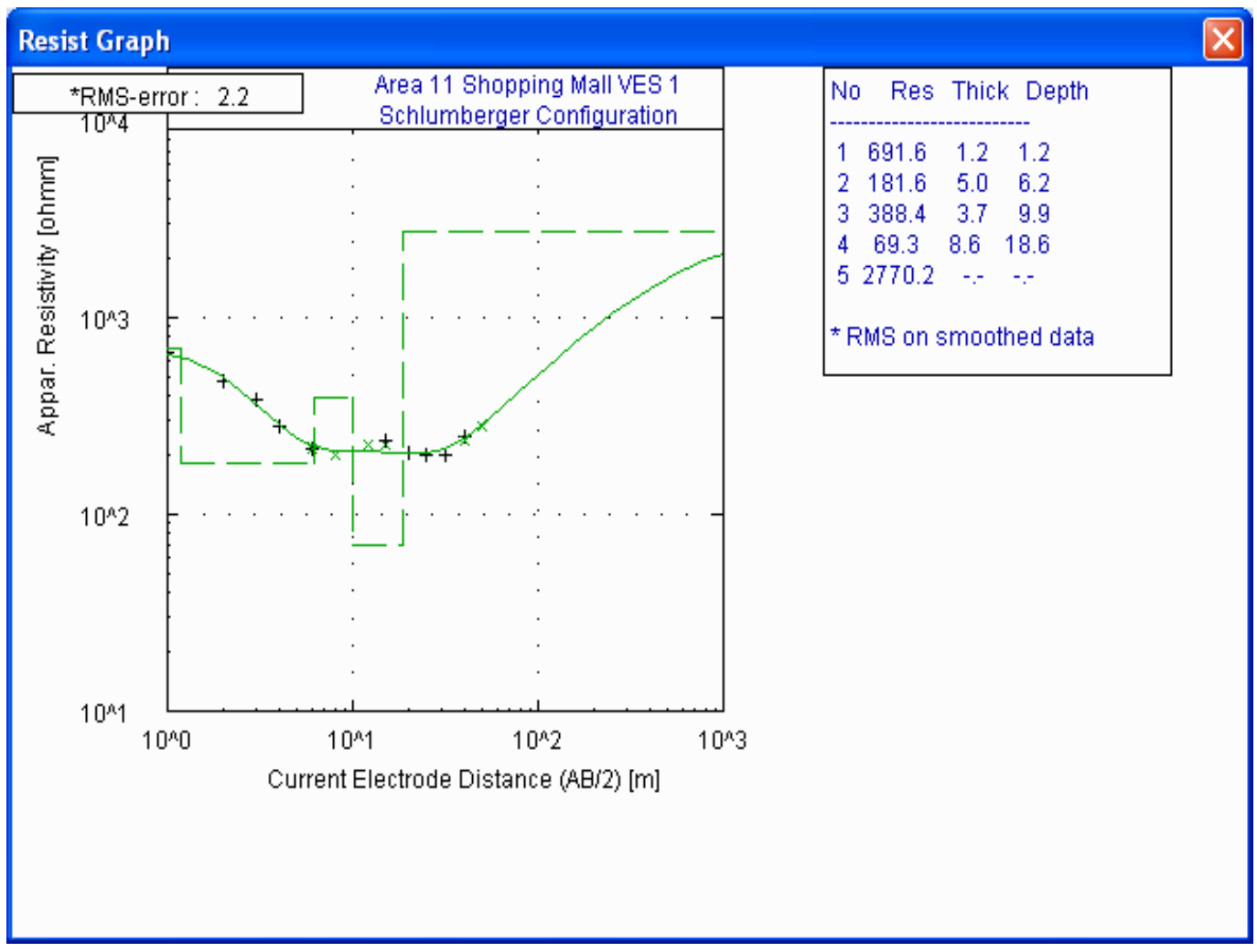

Figure 7. Area 11.

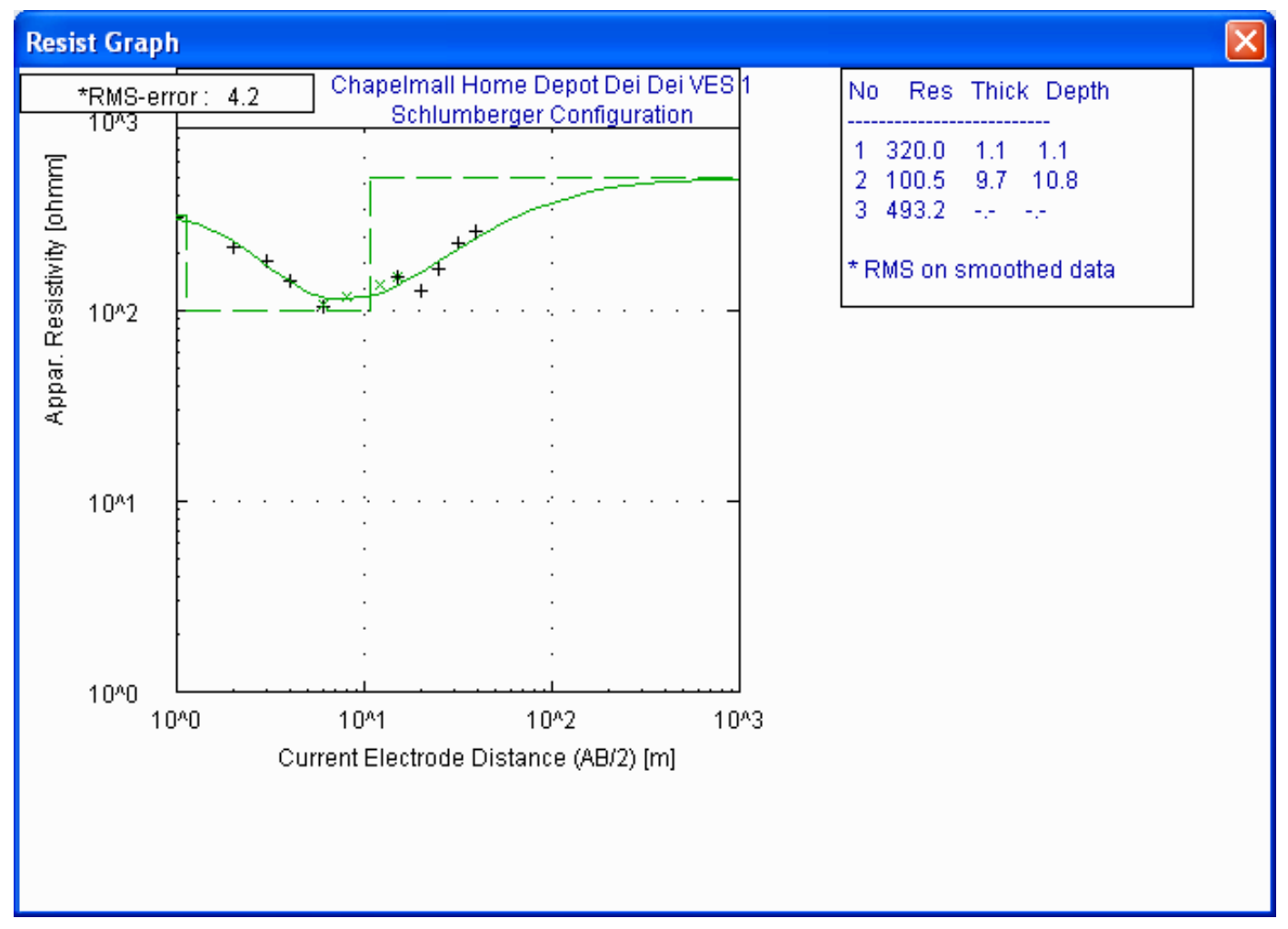

Figure 8. Dei-Dei. 


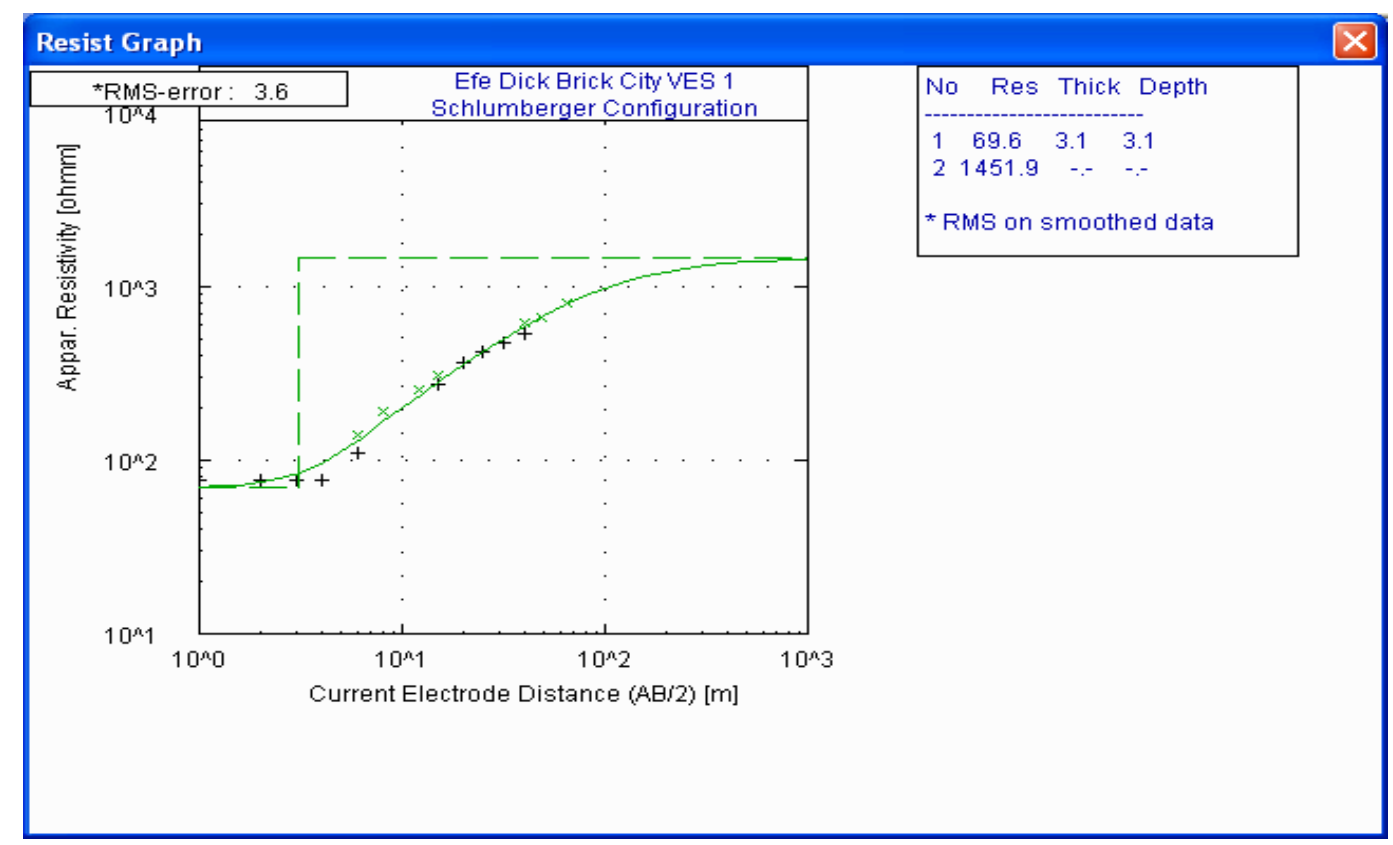

Figure 9. Brick City.

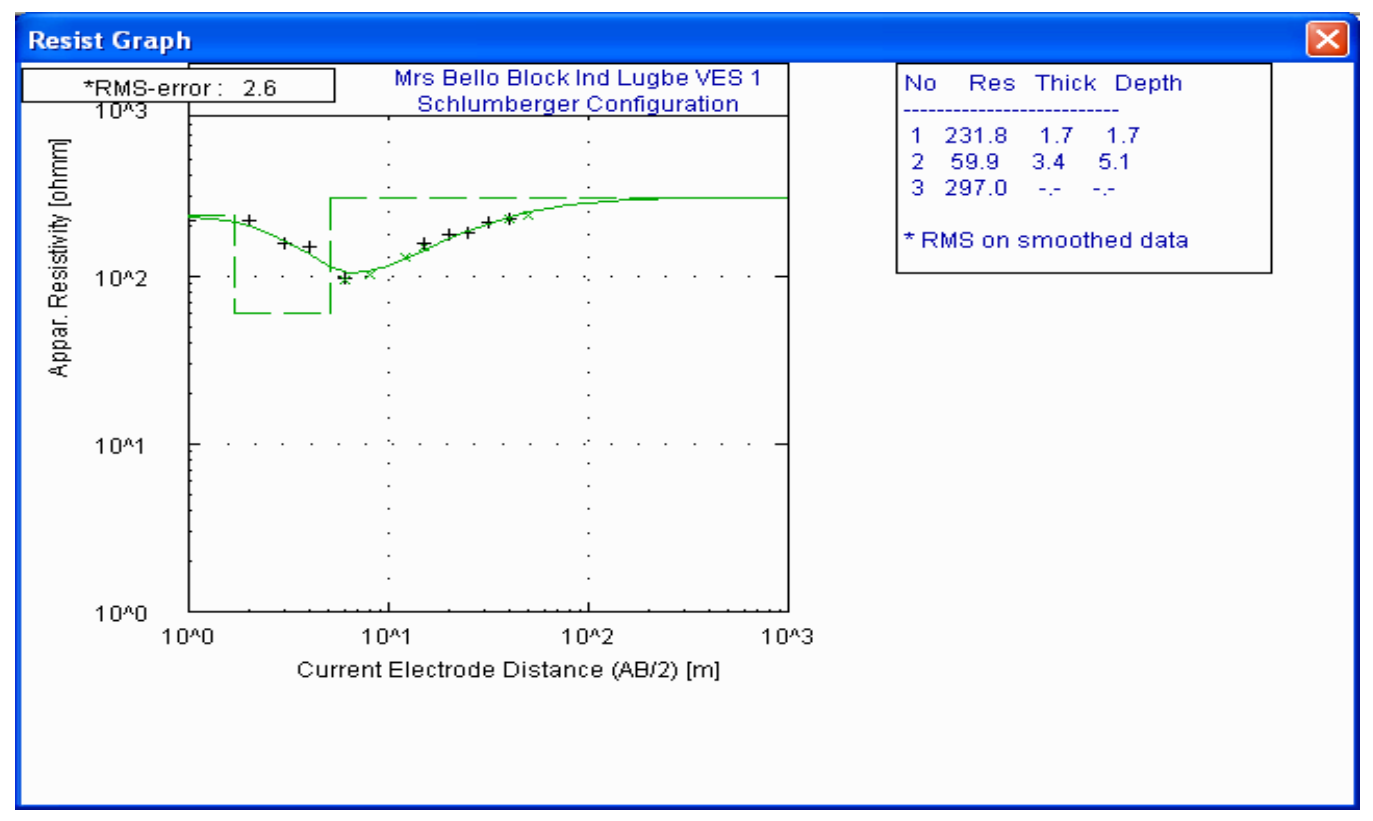

Figure 10. Lugbe.

Site two borehole (S2): Details about the logging are given in Table 3.

\section{DATA INTERPRETATION AND RESULTS}

\section{VES data analysis and interpretation}

Twelve VES points were studied in this work; five from areas around Gosa and seven from other parts of Abuja, (Figure 4). The five points in Gosa area were close to abortive borehole sites. Table 1 shows a summary of the results of the interpretations. The table shows that at the location of VES 1, there is a thick lateritic topsoil of up to $3.4 \mathrm{~m}$, underlain by a thick micaceous sandy clay layer of weathered basement rock that cannot sustain boreholes. This is directly underlain by unweathered, unfractured 
Table 1. Summary of results obtained from the computer output of the eight (12) VES in the area.

\begin{tabular}{|c|c|c|c|c|c|c|c|c|c|c|c|c|c|c|c|c|}
\hline \multirow{2}{*}{$\mathbf{S} / \mathbf{N}$} & \multirow{2}{*}{ VES No. } & \multirow{2}{*}{ Location } & \multicolumn{6}{|c|}{ Resistivities(ohm-m) of geoelectric layers } & \multicolumn{6}{|c|}{ Thickness $(\mathrm{m})$ of geoelectric layers } & \multirow{2}{*}{ Lithology } & \multirow{2}{*}{ Remarks } \\
\hline & & & p1 & $\rho 2$ & p3 & p4 & p5 & p6 & h1 & h2 & h3 & h4 & h5 & h6 & & \\
\hline 1. & VES 1 & Gosa & 83 & 438, & 62 & 236 & 68 & 2067 & 3.4 & 39.3 & $\infty$ & & & & $\begin{array}{l}\text { Lateritic topsoil, weathered } \\
\text { basement, fresh basement }\end{array}$ & Dry \\
\hline 2. & VES 2 & Gosa & 410.6, & 130.5, & 47.72, & 4869 & 164.4 & & 0.44 & 1.22 & 3.33, & 4.88 & $\infty$ & & $\begin{array}{l}\text { Sandy clayey topsoil, fresh } \\
\text { basement }\end{array}$ & Dry \\
\hline 3. & VES 3 & Gosa & 211.2, & 82 & 122 & 54.29, & 1140 & 82043 & 0.6 & 2.03, & 2.86 & 5.97, & 12.48, & $\infty$ & $\begin{array}{l}\text { Sandy topsoil, weathered } \\
\text { basement, fresh basement }\end{array}$ & Dry \\
\hline 4. & VES 4 & Gosa & 1580 & 332.8, & 47.57 & 19369, & 72.7 & & 0.49 & 1.33 & 4.44 & 6.86 & $\infty$ & & $\begin{array}{l}\text { Sandy topsoil, } \\
\text { weathered zone, fresh } \\
\text { basement }\end{array}$ & Dry \\
\hline 5. & VES 5 & Gosa & 184.3 & 1104 & 37.87 & 1473 & & & 0.22 & 2.46 & 12.95 & & & & $\begin{array}{l}\text { Sandy topsoil, weathered } \\
\text { basement, fresh basement }\end{array}$ & Dry \\
\hline 6. & VES 6 & Wuse zone 5 & 94 & 171 & 677 & 298 & & & 1.0 & 2.8 & 2.2 & $\infty$ & & & $\begin{array}{l}\text { Sandy topsoil, clayey sand, } \\
\text { weathered basement }\end{array}$ & Wet \\
\hline 7. & VES 7 & Lugbe & 231 & 59 & 297 & & & & 1.7 & 3.4, & $\infty$ & & & & $\begin{array}{l}\text { Sandy clayey topsoil, } \\
\text { weathered and fractured } \\
\text { basement }\end{array}$ & Wet \\
\hline 8. & VES 8 & Area 11 & 691 & 181 & 388 & 69 & 2770 & & 1.2 & 5.0 & 3.7, & 8.7, & $\infty$ & & $\begin{array}{l}\text { Lateritic topsoil, fractured } \\
\text { basement }\end{array}$ & Wet \\
\hline 9. & VES 9 & Dei-Dei & 320 & 100 & 493 & & & & 1.1 & 9.7, & $\infty$ & & & & $\begin{array}{l}\text { Sandy clay topsoil, } \\
\text { weathered basement }\end{array}$ & Wet \\
\hline 10. & VES 10 & Phase 4 & 42 & 1323 & 217 & 39 & 444 & & 0.9 & 0.3 & 4.6 & 16.4 & $\infty$ & & $\begin{array}{l}\text { Lateritic clay } \begin{array}{r}\text { topsoil, } \\
\text { weathered and fractured } \\
\text { basement }\end{array} \\
\end{array}$ & Wet \\
\hline 11. & VES 11 & Kubwa & 257 & 1219 & 530,1 & 100000 & & & 0.8 & 0.9 & 13.9 & $\infty$ & & & $\begin{array}{l}\text { Sandy clay topsoil, } \\
\text { weathered basement }\end{array}$ & Wet \\
\hline 12. & VES 12 & Brick City Estate & 69 & 1451 & & & & & 3.1 & $\infty$ & & & & & $\begin{array}{l}\text { Sandy clay topsoil, } \\
\text { fractured basement }\end{array}$ & Wet \\
\hline
\end{tabular}


Table 2. Depth and Lithologic Unit of Borehole at Dei-Dei. The drilling point coordinate, Lat. 9 6’52"N and Long. $7^{\circ} 15^{\prime} 39^{\prime \prime} \mathrm{E}$, using GPS, Model: Extrex high sensitivity 2000 to 2007 Garmin Ltd.

\begin{tabular}{cccl}
\hline Sample ID & Depth $(\mathbf{m})$ & Thickness $(\mathbf{m})$ & Lithology description \\
\hline S1L1 & $0-4$ & 4 & Sandstone, brownish and ferruginous, interbedded with quartz feldspar \\
S1L2 & $4-10$ & 6 & Coarse sand with clay, bright red. \\
S1L3 & $10-11.3$ & 1.3 & Slightly micaceous Sandy clay, brownish pebbly, fine to coarse feldspar. \\
S1L4 & $11.3-18.5$ & 7.2 & Fin to coarse sandy clayey and gravel \\
S1L5 & $18.5-24$ & 5.5 & Sand. Brown, clayey at the top, fine to coarse \\
S1L6 & $24-33$ & 9 & Light grey coarse sand, granite gravel \\
S1L7 & $33-45$ & 12 & Silty sand feldspar, blackish to grey \\
S1L8 & $45-49$ & 4 & Grey silty sand, low grade \\
S1L9 & $49-57$ & 8 & Greyish to Purple silty sand \\
S1L10 & $57-64.5$ & 7.5 & Sand, fine to coarse, pebbly blackish to grey \\
\hline
\end{tabular}

Table 3. Depth and Lithologic Unit of Gosa Site Borehole. Coordinate (Lat: 8 56' 45.6” N and Long: $7^{\circ} 13^{\prime} 26.2^{\prime \prime}$ E, GPS- Model: Extrex high sensitivity 2000-2007 Garmin Ltd) was used for coordinate.

\begin{tabular}{cccl}
\hline Sample ID & Depth $(\mathbf{m})$ & Thickness $(\mathbf{m})$ & Lithology description \\
\hline S2L1 & $0-5.6$ & 5.6 & Sandy clay, reddish brown laterite top soil. \\
S2L2 & $5.6-15.6$ & 8 & Sandy clay, fine to medium, brownish to yellow. \\
S2L3 & $13.6-24.9$ & 11.3 & Clay sandy feldspar Yellowish brown pebbly \\
S2L4 & $24.9-32.3$ & 7.4 & Micaceous clayey, grey to black \\
S2L5 & $32.3-41.8$ & 9.5 & Sandy shinny greyish to black feldspar. \\
S2L6 & $41.8-50.8$ & 9 & Fine medium shinny, qartz interbed, greyish ash feldspar \\
\hline
\end{tabular}

basement. VES 2 shows an area with thicker lateritic topsoil underlying fresh basement at a very shallow depth. At the location for VES 3, the unweathered basement is encountered at a deeper depth; yet the area does not sustain a borehole. The location for VES 4 and 5 , the fresh basement is encountered at shallow depth. We are of the opinion that part of the problem in the Gosa area is the occurrence of micaceous clayey sediment in addition to the existence of shallow unfractured basement rocks. The lithology around the other VES points is similar to that of Gosa area described above; however, all the wells are productive.

\section{Borehole log interpretation}

It is clear from the above log that in Dei-Dei, $7.2 \mathrm{~m}$ thickness of the basalt is buried about $4 \mathrm{~m}$ of clay capped by a top laterite bed. The basalt lie directly a thin gravely and sandy layer marked by deep brownish laterite surface. The gravely layers, though highly permeable produces good yield, deep brown in colour, the brown colour resulting from high iron concentration derived from the intensive ferruginisation associated with the ground surface before the volcanic eruption. The fractured bottom layer of the basalt provides less contaminated water.
In Gosa, the coarse granites weather into water bearing sandy residue, the syenitic rock types, with the predominance of unstable minerals eg. Feldspars, decompose into plastic or soft clay and other argillites which behave only as aquitards or aquicludes. Generally, only small amount of water can be obtained or dry well in the freshly unweathered bedrock below the weathered layers. Even when fractured and prevented water from being transmitted into the borehole.

\section{Conclusion}

Results from the VES surveys and well log carried out in the study area indicated the presence of lateritic or sandy topsoil, weathered basement and fractured basement. The similarity in the geoelectric sections suggests a homogenous aquiferous setting in the area. However, this is not the case as boreholes drilled in the Gosa area were dry, even when drilled to depths of over $120 \mathrm{~m}$. Based on the findings stated above, the following conclusions can be made.

(1) In Gosa, the area is inextensive fracturing in younger granite, and not often coincide with the broad depression of valley within the formation. In nature, it situated in an elongated depression simulating one of such situation but 
the hydrogeological information which are the deeply dissected by fractures within the rock formations are not interconnected.

(2) In Dei-Dei, the rock compositions are made up of coarse granitic material, gave relatively higher yields in the apparently fractured or faulted zones which could be the evidence of volcanic activity marked by the occurrence of flat toped lateritised basalt.

In this study, it suggests that most of the successful boreholes in the basement rocks should terminate at the depth of about $60 \mathrm{~m}$ in deeply weathered and fractured zones that are interconnected.

\section{ACKNOWLEDGEMENTS}

The authors would like to thank the ministry of Higher Education (MOHE) for their funding through Universiti Teknologi Malaysia Research Grant Scheme Project. The authors will gratefully acknowledge the Nigerian Geological Survey Agency and Federal Ministry of Water Resources for their support in this work. Thanks to SYB Sinyoung Borehole Limited for providing the Rig machine and Compressor used in drilling the boreholes. Also, to Maxico Hydrosolution consult for providing Campus Ohmega for geosurvey.

\section{REFERENCES}

Acworth RI (1987). The development of crystalline basement aquifers in a tropical Environment. Quart. J. Eng. Geol. 20:265-272.

Ajibade AC, Woakes M, Rahaman MA (1987). Proterozoic crustal development in the Pan-African regime of Nigeria. In Proterozoic lithospheric evolution geodynamics. 17:259-271.

Barongo JO, Palacky GD (1989). Investigation of electrical properties of weather layers in the Yale area, Western Kenya, using resistivity soundings. Geophysics 56:133-138.

Black RR, Caby R, Moussine-Pouchkine A, Bayer R, Bertrand JM, Boullier AM, Fabre J, Lesquer A (1979). Evidence for Late Precambrian plate tectonics in West Africa. Nature 278:223-227.

Caby R (1989). Precambrian terrains of Benin, Nigeria and Northeast Brazil and the Late Proterozoic South Atlantic fit. Geol. Soc. Am. Special Paper. 230:145-158.
Dada SS (2008). Proterozoic evolution of the Nigeria - Boborema province. Geologic Soceity London special publications. 294:121136.

De Beer JH, Blume J (1985). Geophysical and hydrogeological investigation of the groundwater resources of western Hereroland, southwest African/Namibia. Trans. Geol. Soc. S. Afr. 88:483-493.

Edet AE, Okereke CS (1997). Assessment of hydrogeological conditions in basement aquifers of the Precambrian Oban Massif, Southeastern Nigeria. J. Appl. Geophys. 36:95-204.

Mbonu PDC, Ebeniro JO, Ofoegbu CO, Ekine AS (1991). Geoelectrical Sounding for the determination of aquifer Characteristics in part of Umuahia area of Nigeria. Geophysics 56:284-291.

Nur A, Ayuni NK (2004). Hydrologeolectrical study in Jalingo Metropolis and environs of Taraba State, Northeastern Nigeria. Global J. Geol. Sci. 2:101-109.

Obaje NG (2009). Geology and mineral resources of Nigeria. Lecture Notes Earth Sci. pp. 120-221.

Olorunfemi MO, Fasuyi SA (1993). Aquifer types and geoelectrical/hydrogeologic characteristics of the central basement terrain of Nigeria. J. Afr. Earth Sci. 16:309-317.

Olorunfemi MO, Okakune ET (1992). Hydrogeological and Geological significance of Geoelectrical survey of Ile-lfe. Nig. J. Mining Geol. 28:221-222.

Oyawoye MO (1972). The basement complex of Nigeria. In T.F.J. Dessauvagie and A.J. Whiteman (eds). Afr. Geol. Ibadan pp. 66-102.

Pulawski B, Kurtn K (1977). Combined use of resistivity and seismic refraction methods in groundwater prospecting in crystalline areas. Study project. Kenya. DANIDA pp. 5-33.

Rahaman MA (1988). Recent advances in the study of the Basement Complex of Nigeria. Precambrian Geology of Nigeria. Geol. Survey Nig. Pub. pp. 11-43.

Satpatty BN, Kanugo BN (1976). Groundwater Exporation in Hard rock terrain: A case study. Geophys. Prospect. 24:725-736.

Shemang EN (1993). Groundwater potentials of Kubami River Bassin, Zaria, Nigeria, from D. C Resistivity study. Water Res. 2:36-41. 